\title{
KEANEKARAGAMAN JENIS REPTIL DI SEKITAR SUNGAI ASEI KAMPUNG SAOKOREM KABUPATEN TAMBRAUW
}

\author{
(Reptile Species Diversity Around Asei River, Saokorem Village of Tambrauw District) \\ HENDRIKUS R. BURWOS ${ }^{1}$, CHARLIE D. HEATUBUN ${ }^{1}$, MELIZA S. WORABAI ${ }^{1 凶}$ \\ ${ }^{1}$ Jurusan Kehutanan, Fakultas Kehutanan Universitas Papua Manokwari, Papua Barat, 98314. \\ Tlp/Fax: +62986211065. \\ $\triangle$ Penulis Korespondensi: Email: sartjew@gmail.com \\ Diterima: 22 Sept 2020| Disetujui: 20 Okt 2020
}

\begin{abstract}
Abstrak. Tujuan dari penelitian ini adalah mengetahui keanekaragaman dan komposisi spesies reptil pada berbagai tipe habitat di sekitar Sungai Asei. Membandingkan keanekaragaman dan kesamaan jenis reptil pada beberapa tipe habitat. Metode yang digunakan dalam penelitian ini adalah metode deskriptif dengan menggunakan teknik Visual Encounter Survey (VES) atau teknik survei perjumpaan visual. Hasil penelitian yang dilakukan berhasil didata sebanyak 25 jenis reptil yang terdiri dari 12 jenis kadal, 2 jenis biawak, 10 jenis ular, dan 1 jenis penyu. Hasil perhitungan Indeks keanekaragaman jenis $\left(H^{\prime}\right)$ dan kemerataan jenis $\left(E^{\prime}\right)$ tertinggi pada tipe habitat hutan pantai $H^{\prime}(1.43)$ dan diikuti oleh hutan sekunder $H^{\prime}(1.39)$ memiliki tingkat keanekaragaman jenis yang tinggi. Perhitungan indeks Sorensen reptil antara tipe habitat, menunjukkan kisaran indeks antara $50-77$ atau $50-77 \%$, hasil tersebut dapat dilihat bahwa nilai kesamaan jenis semuanya mendekati 1 , yang berarti data ini menunjukkan bahwa jenis reptil yang tersebar pada berbagai tipe habitat di sekitar Sungai Asei yaitu pada hábitat hutan primer, hutan sekunder, dan hutan pantai.
\end{abstract}

Kata kunci: Jenis reptil, keanekaragaman spesies, tipe habitat, herpetofauna

\begin{abstract}
The purpose of this study is to know the various types of reptile species found around Asei river and to compare its diversity and similarity that based on several types of habitus. The study implemented descriptive method by using visual encounter survey (VES) technique. The result found about 25 reptile species which consisted of 12 types of lizard, 2 types of monitor lizard, 10 types of snake and 1 type of turtle. Based on the calculation of species diversity index ( $\left.H^{\prime}\right)$ and species evenness $\left(E^{\prime}\right)$, the higher $H^{\prime}$ was indicated on the coastal forest of 1,43, then followed by secondary forest of 1,39 with high species diversity rate. In addition to the Sorensen index of reptile among those habitat types showed the range index between 50-70\% which has been indicated that the similarity index value for the whole is almost 1. Therefore, it means that reptile have bene spreading over various habitat types surrounding Asei river which are in the primary forest, secondary forest as well as coastal forest.

Keywords: Reptile species, species diversity, habitat type, herpetofauna
\end{abstract}

\section{PENDAHULUAN}

Papua merupakan bagian barat pulau besar Nugini, yang memiliki luas wilayah 416.129 $\mathrm{km}^{2}$ dan mendukung hutan rimba tropis tua terluas yang masih ada di Asia Pasifik (Kartikasari dkk, 2012). Lokakarya konservasi keanekaragaman hayati di Irian Jaya (Sekarang Papua) menyebutkan bahwa Papua Memiliki 20.000 - 25.000 spesies tumbuhan berkayu; 164 spesies mamalia; 329 spesies reptile dan amfibi; 650 spesies burung; 250 spesies ikan air tawar; 150.000 spesies serangga; dan berates ratus 
invertebrata air tawar (Conservation International, 2000).

Sampai saat ini paling sedikit ada 231 spesies reptil yang telah diketahui di Papua. Reptil yang ditemukan di Papua terdiri dari tiga ordo (bangsa) yaitu; Ordo Squamata (kadal dan ular), Testudinata (kura-kura dan penyu), dan Crocodylia (buaya), (Conservation Internasional, 2000). Tercatat kadal di Papua berjumlah 141 spesies, Ular 83 spesies, Kurakura dan Penyu 15 spesies dan Buaya 2 spesies. Krey (2009) menyebutkan bahwa lebih sedikit jumlah spesies reptil di Papua dibandingkan dengan Papua New Guinea, ini disebabkan kurangnya penelitian keanekaragaman reptil di Papua. Keanekaragaman reptil di Papua diperkirakan akan terus bertambah dengan adanya penelitian-penelitian terbaru.

Keragaman flora dan fauna di Papua meliputi rangkaian habitat yang luas, mulai dari daerah dataran rendah hingga pegunungan tinggi (4884 mdpl) di seluruh Asia Tenggara (Petocz, 1987). Beehler and Marshall (2007) menyatakan bahwa endemisitas fauna di Papua meliputi daerah geologi New Guinea, pegunungan yang terisolasi, kepulauan satelit, dan lembah dataran rendah yang berair. Daerah-daerah ini memiliki keendemikan dan kekayaan jenis amfibi dan reptil yang tinggi. Workshop yang diselenggarakan oleh Conservation International (CI) tentang Prioritas Konservasi Biodiversitas di Irian Jaya (sekarang Papua) mengidentifikasi 19 wilayah endemis penting amfibi dan reptil. Kampung Saukorem merupakan salah satu wilayah yang termasuk dalam prioritas konservasi herpetofauna pada Daerah Pegunungan Tambrauw dan Arfak (Conservation International, 1999). Di daerah Tambrauw terdapat berbagai sungai besar dan sungai kecil. Salah satu sungai yang terdapat di Tambrauw yaitu Sungai Asei.

Sungai Asei merupakan salah satu sungai yang berdekatan dengan Kampung Saukorem di
Tambrauw, daerah aliran Sungai Asei termasuk dalam salah satu dari 3 (tiga) kelompok pegunungan besar di wilayah kepala burung tepatnya di Cagar Alam Pegunungan Tambrauw Utara. Kondisi lingkungan sekitar Sungai Asei merupakan kondisi lingkungan yang mendukung adanya spesies reptil. Kondisi tersebut merupakan kondisi yang cocok untuk habitat reptil. Berdasarkan kondisi lingkungan tersebut maka perlu di lakukan penelitian mengenai keberadan spesies reptil di sekitar sungai tersebut. Tujuan dari penelitian ini adalah untuk mengetahui keanekaragaman dan komposisi spesies reptil pada berbagai tipe habitat di sekitar sungai Asei serta membandingkan keanekaragaman dan kesamaan jenis reptile pada beberapa tipe habitatnya.

\section{METODE PENELITIAN}

Penelitian ini dilakukan disekitar bantaran Sungai Asei Kampung Saukorem yang berlangsung selama \pm (1) Minggu terhitung dari tanggal 2 Mei sampai dengan tanggal 9 Mei tahun 2016. Alat yang digunakan dalam penelitian ini adalah Global Possitioning System (GPS) Map 60 Csx, rool meter, tali rafia, senter (senter kepala dan senter tangan), karet gelang, kamera digital, disecting set, kaliper mini, kantung spesimen (plastik dan kain), kotak presevasi (kotak plastik), toples plastik, label spesimen dan tongkat kayu berbentuk huruf (Y). Selain itu digunakan buku catatan lapangan, dan, buku identifikiasi. Sedangkan bahan yang digunakan adalah tissue, Formalin 10\% dan Alkohol 70\%.

\section{Metode dan Teknik}

Metode yang digunakan dalam penelitian ini adalah metode deskriptif dengan menggunakan teknik Visual Encounter Survey (VES) atau teknik survei perjumpaan visual (Conservation International, 2000). Metode ini dilakukan secara diurnal dan nokturnal yaitu pengamatan 
pada siang serta malam, melalui jalur transek pengamatan.

\section{Variabel Penelitian}

Variabel penelitian terdiri dari variabel utama dan variabel penunjang, yaitu:

A. Variabel Uatama

1. Jenis reptil (kadal, ular dan penyu)

2. Bentuk morfologi dari jenis kadal, ular dan penyu

3. Jumlah individu tiap jenis dari tiap reptil yang dijumpai

4. Morfometrik dari tiap jenis reptil yang dijumpai

a. Jenis kadal dilhat dari snout to vent length (SVL)/ panjang tubuh dan panjang ekor.

b. Jenis ular dilihat dari (SVL)/panjang tubuh, panjang total,

c. Jenis penyu dilihat dari panjang dan lebar kepala, panjang dan lebar karapas, dan warna.

B. Variabel Penunjang

1. Ketinggian tempat

2. Deskripsi tipe habitat

\section{Prosedur Penelitian}

\section{A. Persiapan}

Persiapan awal yang dilakukan sebelum melakukan pengamatan, yaitu menentukan lokasi pengamatan dengan menggunakan GPS, kemudian pada lokasi yang telah ditetapkan, dilakukan pembuatan transek pengamatan sepanjang $1 \mathrm{Km}$ pada ketiga habitat yang telah ditentukan, yang dilakukan pada siang hari sebagai jalur pengumpulan data.

B. Proses pengumpulan data

Waktu pengamatan serta pengumpulan sampel reptil dalam penelitian ini dilakukan dua kali sehari yaitu pada siang hari pukul 09.00-12.00 WIT dan pada malam hari pukul 17.00- 22.00 WIT. Pengamatan dilakukan pada jalur transek yang dibuat di sekitar bantaran sungai Asei. Jenis reptil yang dijumpai dicatat karakter morfologinya. untuk jenis kadal ditangkap dengan menggunakan karet gelang dan untuk jenis ular ditangkap dengan menggunakan kayu bercabang seperti huruf (Y). Jenis kadal yang berukuran kecil ditangkap dimasukan kedalam plastik spesimen dan untuk jenis ular dan kadal yang berukuran agak besar ditangkap dan dimasukan kedalam kantung spesimen yang telah di beri no/label spesimen. Setelah itu dilakukan pencatatan kondisi habitat, keadaan cuaca dan ketinggian tempat.

C. Pembuatan Spesimen

Pembuatan spesimen diawali dengan mendokumentasikan jenis reptil yang ditemukan tersebut. Setelah itu dilakukan pengukuran tubuh. Spesimen dibuat guna untuk proses identifikasi lanjutan. Pembuatan spesimen di buat dalam bentuk spesimen basah. Pembuatan spesimen basah dilakukan untuk jenis reptil yang berukuran kecil.

\section{Preservasi}

Presevasi (pembiusan) dengan cara memasukan jenis reptil kedalam wadah yang berisikan cairan alkohol, khususnya untuk jenis reptil yang berukuran kecil sedangkan untuk jenis reptil yang berukuran besar disuntik dengan menggunakan alkohol $70 \%$.

2. Fiksasi

Fiksasi dilakukan dengan menggunakan formalin yang bertujuan agar jaringan menjadi kaku. Untuk jenis reptil yang bertubuh besar formalin disuntik kedalam rongga perut, ekor dan anggota badan (Sidik dan Mumpuni, 1999).

Fiksasi dibuat dalam baki plastik yang ditutup rapat. Baki tersebut diisi dengan formalin 10\% secukupnya, kemudian dilapisi dengan lembaran-lembaran tissue. Spesimen diatur dengan posisi 
yang baku di dalam wadah, selanjutnya label yang berisi nomor spesimen diikat pada bagian femur spesimen. Permukaan spesimen dilapisi/ditutupi tissue lalu disiram/dipercikan dengan formalin hingga seluruh permukaan tissue menjadi basah. Setelah semua tissue menjadi basah, wadah ditutup rapat dan dibiarkan selama 2-3 hari. Kemudian setelah itu dicuci dengan air mineral untuk kemudian direndam dalam alkohol.

D. Identifikasi Jenis

Proses identifikasi menggunakan buku identifikasi yaitu jenis O'Shea (1996) untuk mengidentifikasi jenis ular, Brown (1991) untuk identifikasi jenis kadal (Famili Scincidae), McCoy (1980) untuk jenis Reptil. Untuk Identifikasi juga dilakukan bersama Bapak Keliopas Krey, salah satu staf pengajar pada Jurusan Biologi, FMIPA, UNIPA Ahli Herpetofauna dari Kelompok Papua (KHP).

\section{Analisis Data}

Data yang diperoleh dianalisis secara deskriptif dan tampilkan dalam bentuk tabel dan gambar. Untuk menentukan Keanekaragaman reptil pada setiap tipe penutupan lahan di sekitar sungai Asei, maka digunakan indeks keanekaragaman ShannonWiener. Dimana indeks ini mengasumsikan bahwa individu-individu terambil secara acak dari populasi besar yang tidak terbatas dan semua spesies terwakili dalam sampel. Persamaan indeks keanekaragaman ShannonWiener (Magurran, 1988) adalah sebagai berikut :

$$
\begin{aligned}
& H^{\prime i}=-\sum p_{i} \cdot \ln \left(p_{i}\right) \\
& =-\sum\left(\frac{n}{N}\right) \cdot \ln \left(\frac{n_{i}}{N}\right)
\end{aligned}
$$

Keterangan:

$\mathrm{H}^{\prime}=$ indeks Keanekaragaman Shannon spesies ke-i

$\mathrm{p}_{\mathrm{i}}=$ Proporsi individu yang terdapat pada

$\mathrm{n}_{\mathrm{i}}=$ jumlah individu spesieske- $\mathrm{i}$

$\mathrm{N}=$ total jumlah individu semua jenis yang di temukan

Kisaran hasil perhitungan indeks keanekaragaman $(\mathrm{H})$ menurut (Magurran, 1988). menunjukkan bahwa jika:

$H^{\prime}<1,0$ :

- Keanekaragaman rendah,

- Miskin (produktivitas sangat rendah) sebagai indikasi adanya tekanan ekologis yang berat, dan

- Ekosistem tidak stabil

$1,0<\mathrm{H}^{\prime}<3,322$ :

- Keanekaragaman sedang,

- Produktivitas cukup,

- Kondisi ekosistem cukup seimbang,

- Tekanan ekologis sedang.

$\mathrm{H}^{\prime}>3,322$ :

- Keanekaragaman tinggi,

- Stabilitas ekosistem mantap, produktivitas tinggi,

Selain itu, dari indeks keanekaragaman Shannon-Wiener selanjutnya akan dihitung indeks kemerataan (Evenness) yaitu

$$
\mathbf{E}=\mathbf{H}^{\prime} / \ln \mathbf{S}
$$

Keterangan:

$\mathrm{E}=$ Indeks kemerataan Jenis (nilai antara $0-10$ )

$\mathrm{H}^{\prime} \quad=$ Indeks Shannon-Wiener

Ln $=$ logaritma natural

$\mathrm{S} \quad=$ Jumlah Jenis

Kemerataan jenis memiliki nilai indikator $\mathrm{E}$ $=1$ Apabila nilai $\mathrm{E}=1$ berarti pada habitat tersebut tidak ada jenis reptil yang mendominasi. Untuk membandingkan tingkat kesamaan jenis (species similarity) antara tipe habitat, dengan menggunakan rumus sebagai berikut. (Magurran, 1988) 


$$
\mathrm{SS}=\frac{2 \mathrm{C}}{(\mathrm{A}+\mathrm{B})} \times 100
$$

Keterangan:

SS :Sorensen Index

C : Jumlah jenis yang ditemukan pada dua tipe habitat/lokasi (A dan B)

a : Jumlah jenis pada tipe habitat/lokasi A

b : Jumlah jenis pada tipe habitat/lokasi B

\section{HASIL DAN PEMBAHASAN}

Jenis Reptil Yang Di Jumpai

Berdasarkan penelitian yang dilakukan berhasil didata sebanyak 25 jenis reptil, yang terdiri dari 12 jenis kadal, 2 jenis biawak, 10 jenis ular, dan 1 jenis penyu. Jumlah reptil untuk masing-masing taksa dapat dilihat pada Gambar 1.

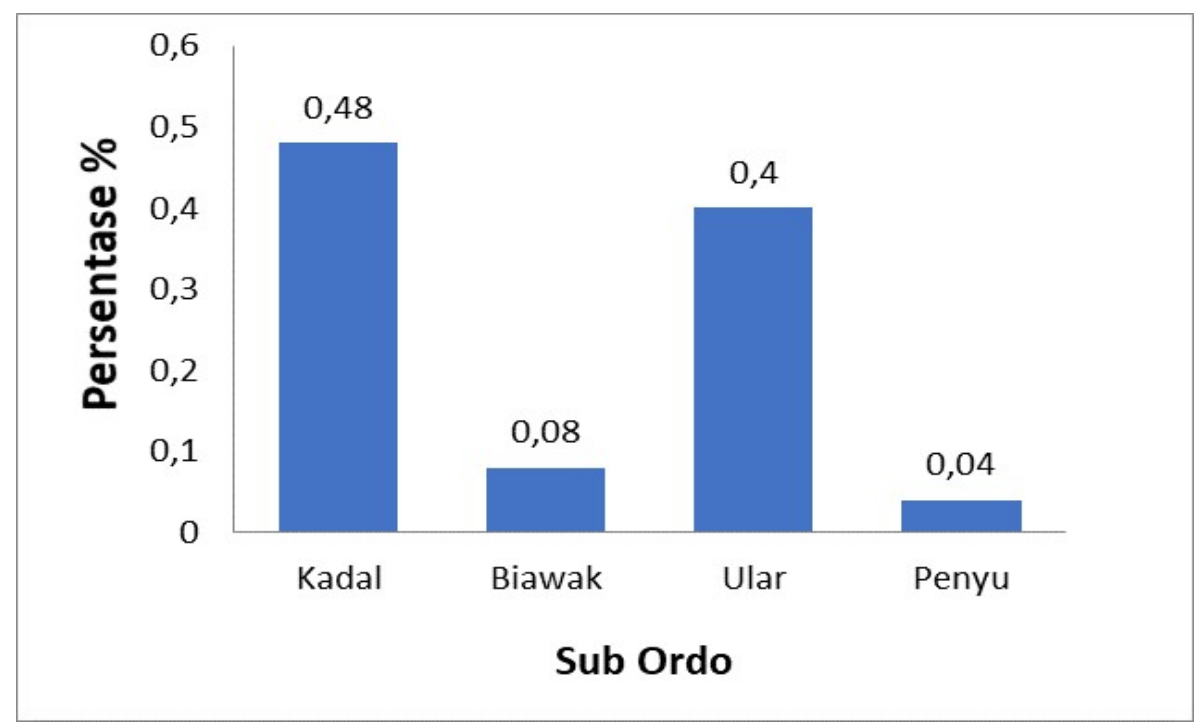

Gambar 1. Diagram jumlah reptil per sub ordo yang di jumpai di sekitar sungai Asei

Berdasarkan diagram pada gambar 1 dapat di lihat bahwa dari ke empat sub-ordo tersebut diketahui jenis yang paling banyak di jumpai yaitu dari jenis kadal sebanyak $(0.48 \%)$, diikuti jenis ular, $(0.4 \%)$, dimana jenis kadal dan ular pada saat pengamatan di jumpai pada semua tipe habitat (hutan primer, hutan sekunder dan hutan pantai). Ketiga habitat tersebut sangat mendukung keberadaan kadal dan ular dalam hal mencari makan dan berkembangbiak. Sedangkan jenis yang paling rendah adalah penyu $(0.04 \%)$, yang hanya dijumpai pada hutan pantai. Penyu merupakan reptil yang hidup dan berkembangbiak dan mencari makan di lautan. Pada bulan tertentu penyu akan mendarat ke tepian pantai untuk meletakkan telur-telurnya di sepanjang pantai yang sangat cocok untuk penyu tersebut meletakan telurnya. Conservation Internasional (2000) menyebutkan bahwa sampai saat ini paling sedikit ada 231 spesies reptil yang telah diketahui di Papua. Beehler and Marshall 2007 menyebutkan bahwa tercatat kadal di Papua berjumlah 141 spesies, ular 83 spesies, kurakura dan penyu 15 spesies dan buaya 2 spesies.

Dari keempat sub ordo reptil yang di jumpai, terbagi lagi kedalam 9 famili yang dijumpai dari tiga tipe habitat yaitu famili Scincidae 8, Geckonidae 3, Agamidae 1 , Varanidae 2, Boidae 3 , Colubridae 5, Pythonidae 1, Elapidae 1, Cheloniidae 1. (Gambar 2). 


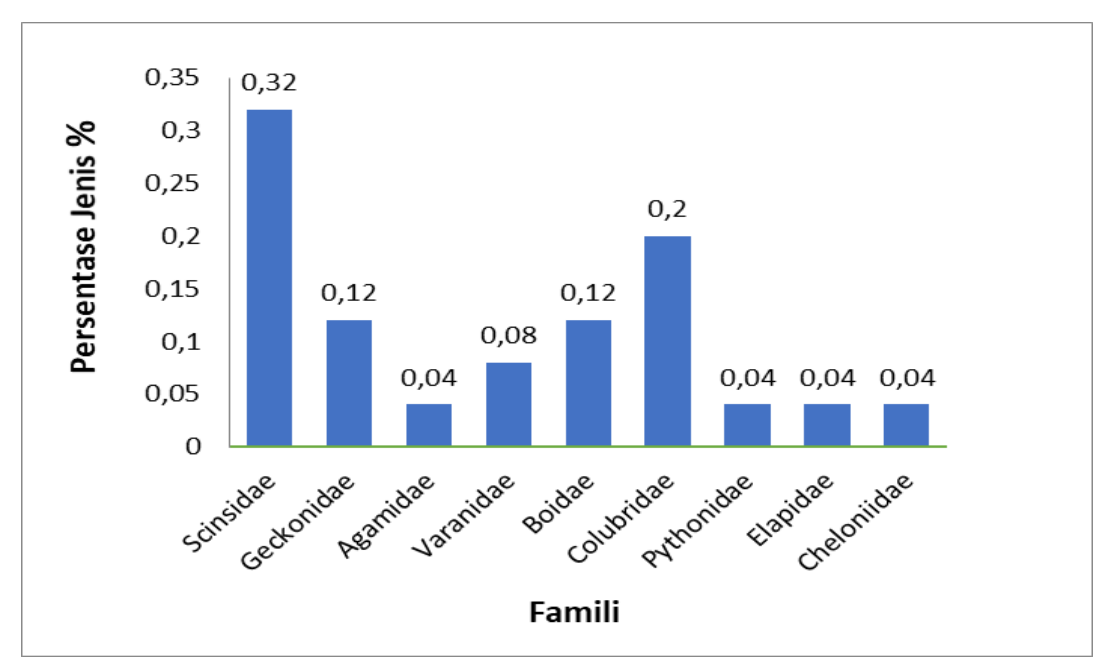

Gambar 2. Diagram persentase jumlah jenis per famili

Dari diagram di atas dapat dilihat bahwa jenis reptil yang ditemukan pada tiga tipe habitat di sekitar sungai Asei didominasi oleh famili Scincidae yaitu sebanyak $(0.32 \%)$ jenis. Sedangkan famili yang paling rendah dijumpai yaitu masing-masing dari famili Agamidae, Pythonidae, Elapidae, dan Cheloniidae yaitu (0.04\%). Jumlah reptil dari famili Scincidae paling banyak dalam hal jumlah dan jenis serta tersebar pada tiga tipe habitat pada lokasi penelitian, sedangkan untuk ketiga famili yang paling rendah masing-masing dijumpai pada tipe habitat hutan sekunder dan hutan pantai.

Berdasarkan diagram pada gambar 1, persentase famili reptil per jumlah individu yang terbesar adalah dari famili Scinsidae 84 individu, kemudian di ikuti oleh famili Geckonidae 32 individu , sedangkan famili yang terendah yaitu Agamidae 1 individu dan Pythonidae 1 individu. Persentase jumlah individu dari 9 famili reptil yang di jumpai dapat dilihat pada Gambar 3.

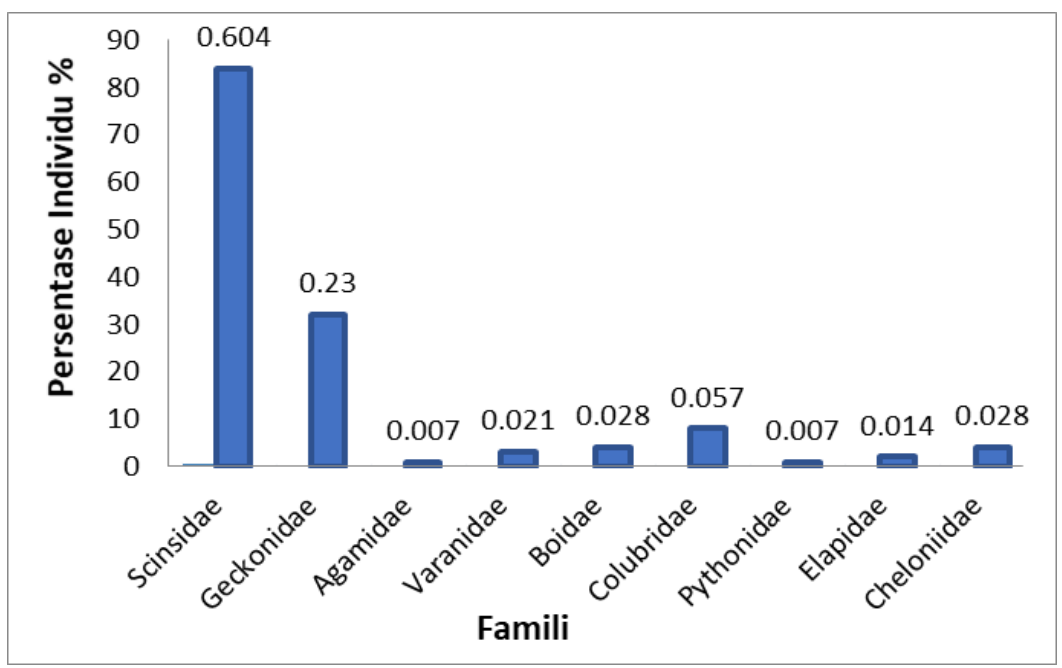

Gambar 3. Diagram persentase jumlah individu per famili 
Reptil yang ditemukan pada tiga tipe habitat di sekitar sungai Asei didominasi oleh famili Scincidae yaitu sebanyak $(0,604 \%)$, hal ini dikarenakan famili Scincidae yang ditemukan habitat pada ketiga lokasi pengamatan sangat mendukung akan kehadiran dari famili Scincidae, baik itu dalam hal pakan maupun tempat hidup, selain itu pada saat pengamatan jenis dari famili Scincidae memiliki penyebaran yang cukup merata baik pada hutan pantai, hutan sekunder dan hutan primer. Pada ketiga tipe habitat tersebut populasi famili Scincidae cukup tinggi, serta jumlah jenis yang cukup banyak dibandingkan delapan famili lainnya. Selain itu, famili Agamidae dan Pythonidae masing-masing jenis memilik jumlah individu 1 $(0,007 \%)$, kedua famili tersebut memiliki jumlah individu yang sedikit dikarenakan kedua famili tersebut merupakan hewan nokturnal yang mana memiliki kebiasan beraktifitas pada malam hari, dan kedua famili tersebut merupakan reptil yang hidupnya arboreal sehingga hal tersebut yang membuat kesulitan untuk menjumpai kedua famili tersebut, selain itu juga faktor lain yang mempengaruhi ketidak hadiran kedua famili tersebut yaitu faktor cuaca, dimana diketahui bahwa pada saat pengumpulan data pada ketiga lokasi, cuaca pada sore dan malam hari pada ketiga lokasi pengamatan sering diguyur hujan, hal ini yang juga memyebabkan tingkat perjumpaan dari kedua famili tersebut menjadi kurang. McCoy (1980) menyatakan jenis Scincidae menempati urutan pertama untuk jenis kadal di New Guinea karena famili ini kosmopolitan, serta persebaranya luas. Famili Scincidae dijumpai pada ketiga tipe habitat yang berada di Sungai Asei, yaitu hutan Primer, hutan Sekunder dan hutan Pantai, sedangkan famili yang terendah adalah Agamidae, Pythonidae, Elapidae, Cheloniidae, masing-masing $1(0.04 \%)$ Jenis. Jenis reptil yang ditemukan terdapat beberapa jenis yang dilindungi oleh Peraturan Pemerintah (PP No. 7 Tahun 1999) dan dalam CITES dan IUCN yaitu Varanus salvador (appendiks II), Varanus indicus (appendiks II) dan Chelonia mydas IUCN, yaitu terancam punah dan CITES (Appendiks I). Dari Sembilan famili yang terdata satu famili di antaranya termasuk famili yang berbisa yaitu dari famili Elapidae (Micropecis ikaheka). Zug (1993) menyebutkan Elapidae merupakan famili yang anggotanya kebanyakan ular berbisa yang banyak ditemukan di daerah tropis dan subtropis dan memiliki bisa tipe neurotoxin.

\section{Indeks Keanekaragaman Jenis Reptil Yang di Jumpai}

Dari pengumpulan data yang dilakukan di sekitar sungai Asei, selama 9 hari berhasil di data 25 jenis reptil, yang terdiri dari 9 famili. Analisis keanekaragaman jenis dan kemerataan jenis di hitung dengan menggunakan rumus Indeks Keanekaragaman Jenis $\left(H^{\prime}\right)$ dan Indeks Kemerataan Jenis $\left(E^{\prime}\right)$. Dapat di lihat pata tabel 1.

Tabel 1. Hasil perhitungan indeks keanekaragaman $\left(H^{\prime}\right)$ dan indeks kemerataan $\left(E^{\prime}\right)$ reptil

\begin{tabular}{llcccc}
\hline \multirow{2}{*}{ No } & \multirow{2}{*}{ Lokasi Pengamatan } & \multicolumn{2}{c}{ Jumlah } & \multirow{2}{*}{$\mathrm{H}^{\prime}$} & \multirow{2}{*}{ E } \\
\cline { 3 - 4 } & & Individu & Spesies & & \\
\hline 1 & Hutan Primer & 38 & 10 & 1.26 & 0.54 \\
2 & Hutan Sekunder & 57 & 18 & 1.39 & 0.47 \\
3 & Hutan Pantai & 46 & 18 & 1.43 & 0.49 \\
\hline
\end{tabular}

Berdasarkan hasil perhitungan tabel 1 dapat di lihat bahwa nilai keanekaragam jenis dan kemerataan jenis masing-masing tipe habitat hampir sama. Hasil perhitungan Keanekaragaman dan kemerataan jenis tertinggi terdapat di tipe habitat hutan pantai dan di ikuti 
dengan hábitat hutan sekunder, sedangkan untuk keanekaragaman jenis dan kemerataan jenis terendah terdapat pada tipeh hábitat hutan primer.

Hasil perhitungan Indeks keanekaragaman jenis (H') dan kemerataan jenis (E') pada tabel 1 menunjukkan perbandingan jenis antara habitat, yang mana keanekaragaman jenis $\mathrm{H}^{\prime}$ tertinggi pada tipe habitat hutan pantai $H^{\prime}$ (1.43) dan diikuti oleh hutan sekunder $H^{\prime}$ (1.39) memiliki tingkat keanekaragaman jenis yang tinggi. Keanekaragaman antar habitat menunjukkan perbedaan komposisi jenis antar tipe habitat. Tingginya keanekaragaman jenis reptil pada tipe habitat hutan pantai dan hutan sekunder dibandingkan dengan tipe habitat hutan primer, Tingginya keanekaragaman jenis $\left(H^{\prime}\right)$ reptil pada tipe habitat hutan pantai dan hutan sekunder dibandingkan dengan tipe habitat hutan primer, hal ini disebabkan karena pada kedua habitat hutan sekunder dan hutan pantai di sekitar sungai Asei merupakan lokasi yang telah dibuka oleh masyarakat untuk berladang, dan juga banyak sekali bekas perladangan pada kedua habitat yang ditumbuhi semak belukar, dengan itu maka menjadi habitat bagi pakan reptil seperti serangga, reptil kecil, amfibi, mamalia kecil dan lain-lain. Kondisi vegetasi yang tumbuh pada hutan sekunder dan hutan pantai yang heterogen juga menyebabkan lebih banyak ditemukan jenis reptili sehingga pada kedua tipe habitat ini memiliki keanekaragaman jenis yang cukup tinggi. Kemerataan tertinggi dijumpai pada tipe habitat hutan pantai (0.49), hal ini disebabkan individu-individu yang dijumpai di hutan pantai terdistribusi secara merata.

Keanekaragaman antar habitat menunjukkan perbedaan komposisi jenis antar tipe habitat. Meskipun telah diketahui keanekaragaman tertinggi terdapat pada tipe habitat hutan pantai yakni dengan kisaran $H^{\prime} 1.43$, namun dalam penetapan kisaran untuk menilai tinggi rendahnya suatu keanekargaman dalam suatu ekosistem, telah ditetapkan suatu kisaran yang dipakai sebagai suatu acuan untuk menilai suatu ekositem, dimana menurut Magurran (1988) menyebutkan bahwa kisaran hasil perhitungan indeks keanekaragaman $\left(H^{\prime}\right)$, menunjukkan bahwa apabila nilai : $\mathrm{H}>3$ : maka keragaman spesies tinggi; dan apabila $1<\mathrm{H}<3$ : Keragaman spesies sedang; $\mathrm{H}<1$ : Keragaman spesies rendah; jika dilihat dari kisaran yang talah ditentukan, maka hasil perhitungan dari ketiga habitat yakni memiliki kisaran nilai rata-rata keanekaragaman jenis antara $1.26-1.43$, yang masuk dalam kisaran antara $1<\mathrm{H}<3$ artinya memiliki keragaman spesies yang sedang, dan juga dinilai berdasarkan skoring yang ditetapkan maka ketiga habitat memiliki, produktivitas cukup, kondisi ekosistem cukup seimbang, tekanan ekologis sedang, yang berati reptil pada ketiga habitat memiliki produktivitas yang cukup dan kondisi ekosistem yang cukup seimbang namun tekanan ekologis sudah mulai meningkat.

Rendahnya keanekaragaman jenis $\left(H^{\prime}\right)$ dan Kemerataan jenis $\left(E^{\prime}\right)$ pada tipe habitat hutan primer hal ini dikarenakan tipe vegetasi yang sangat rapat sehingga mempersulit cahaya matahari untuk menembus kedalam lantai hutan, dan juga topografi pada lokasi tersbut sangat curam dengan kelerengan berkisar \pm 15 $45^{\circ}$ selain itu faktor lain yang sangat mempengaruhi ketidakhadiran jenis reptil pada saat pengamatan pada habitat hutan primer yaitu cuaca, dimana pada saat waktu pengamatan terutama pada malam hari sering terjadi hujan, sehingga mempengaruhi perjumpaan spesies pada lokasi tersebut. Hal yang sama juga diutarakan oleh Matisson (1992) yang menyatakan bahwa faktor-faktor yang mempengaruhi hubungan makhluk hidup dengan lingkungannya adalah suhu, panas, cahaya matahari dan kelembaban. Terdapat enam faktor yang saling berkaitan yang menentukan naik turunnya keragaman jenis suatu komunitas, yaitu: waktu, heterogenitas, 
ruang, persaingan, pemanasan, kestabilan lingkungan dan produktivitas. Menurut Campbell (2004), faktor-faktor yang mempengaruhi keanekaragaman dalam komunitas alamiah meliputi: ketersediaan energi, heterogenitas habitat, spesialisasi relung dan interaksi populasi. Menurut Goin (1971) bahwa faktor yang mempengaruhi keanekaragaman yaitu kecocokan terhadap uhu, elembaban, penutupan tajuk dan formasi tanah.

\section{Indeks Kesamaan Jenis}

Indeks kesamaan (Indeks Sorensen) jenis bertujuan untuk melihat kesamaan jenis reptil pada berbagai tipe habitat. Tiga tipe habitat yang dibandingkan yaitu Hutan Primer, Hutan Sekunder dan Hutan Pantai. Hasil perhitungan indeks kesamaan jenis reptil antara tiga tipe habitat dapat dilihat pada tabel 2.

\section{Tabel 2. Hasil perhitungan indeks kesamaan jenis reptil antara tipe habitat}

\begin{tabular}{lcccc}
\multicolumn{1}{c}{ Lokasi yang di perbandingkan } & C & A & B & SS \\
\hline H. Primer - H. Sekunder & 7 & 10 & 18 & 50 \\
H. Primer - H. Pantai & 7 & 10 & 18 & 50 \\
H. Sekunder - Pantai & 14 & 18 & 18 & 77 \\
\hline \multicolumn{5}{l}{ Keterangan : } \\
$\quad$ C.jenis pada lokasi A dan B, A. jenis pada lokasi A, B. jenis pada lokasi B, SS. Sorensen Index
\end{tabular}

Perhitungan indeks sorensen reptil antara tipe habitat pada tabel 2, menunjukkan kisaran indeks antara 50 - 77 atau 50 - 77\%, hasil tersebut dapat dilihat bahwa nilai kesamaan jenis semuanya mendekati 1 , yang berarti data ini menunjukkan bahwa jenis reptil yang tersebar pada berbagai tipe habitat di sekitar sungai Asei yaitu pada hábitat hutan primer, hutan sekunder, dan hutan pantai, memiliki kesamaan yang rendah atau perbedaan yang tinggi. Rendahnya tingkat kesamaan jenis reptil ini disebabkan karena kebiasaan hidup (seperti pada batang pohon besar, semak belukar, lubang pohon, kayu lapuk yang tumbang, ditepi sungai dll) dan mikrohabitatnya, (hutan primer, hutan sekunder, hutan pantai, perkebunan, bekas perladangan), selain itu juga diduga disebabkan oleh keadaan cuaca yang kurang baik pada saat pengamatan serta lingkungan yang telah berubah.

Jenis reptil di sekitar sungai Asei tersebar pada habitat fossorial hingga arboreal. Jenis fossorial seperti Tribolonotus novaeguinea, terestrial seperti Emoia caureliocauda, Spenomorphus simus, Varanus indicus,
Leopython albertisi, serta Stegonotus diehlii, dan arboreal seperti Lamprolapis samrgandina, Cryptoblepharus novaeguineae dan Varanus prasinus. Selain kedua hábitat tersebut yang biasanya di manfaatkan untuk tempat hidup reptil, terdapat satu jenis reptil yang hanya di jumpai pada daerah hutan pantai yang mana jenis reptil tersebut merupakan jenis yang sepanjang hidupnya berada dilaut dan sekalikali akan kedarat untuk meletakkan telurnya, jenis tersebut yaitu penyu.

\section{Lokasi dan Tipe Habitat}

Letak suatu lingkungan dan tipe habitat tidak hanya menyediakan kebutuhan hidup suatu organisme melainkan tentang dimana dan bagaimana satwa tersebut dapat hidup, selain itu juga apabilan letak habitat yang berbedabeda juga pempengaruhi kehadiran dari suatu spesies (reptil). Jenis reptil di sungai Asei, tersebar di tiga tipe habitat, yaitu pada hutan primer, dan hutan sekunder, hutan pantai. Ketiga habitat tersebut terletak dari hulu sungai ke hilir sungai. 


\section{a. Habitat Hutan Primer}

Hutan primer yang terdapat di hulu Sungai Asei terletak pada kordinat S. $00^{\circ} 36$ 57.8'; E. $133^{\circ} 09^{\circ} 01.3^{\prime \prime}$, dengan ketinggian tempat 179$500 \mathrm{~m}$ dpl. Topografi pada lokasi hutan primer memiliki kemiringan lereng yang cukup curam dengan kisaran kemiringan lereng $15-45^{\circ}$. Hutan tersebut merupakan salah satu hutan yang sering dikunjungi masyarakat kampung Saukorem. Masyarakat memanfaatkan hutan tersebut sebagai tempat berburu satwa. Vegetasi yang tumbuh pada lokasi hutan tersebut sangat rapat dan padat, bahkan terdapat beberapa pohon yang memiliki diameter batang lebih dari $100 \mathrm{~cm}$.

\section{b. Hutan sekunder}

Jalur pada hutan sekunder terletak di bagian daerah pertengaan sungai yaitu tepatnya di antara daerah hulu dan hilir sungai, pada kordinat S,00³5'004 E 133'10'22.3' dengan ketinggian tempat $45-130 \mathrm{~m}$ dpl, dengan topografi yang relatif naik karena lokasi ini berdekatan langsung dengan gunung, dengan kemiringan sekitar $15-30^{\circ}$. Penutupan tajuk pada jalur pengamatan hutan sekunder cukup rapat, permukaan tanah ditutupi oleh semak belukar. Vegetasi yang dominan pada tipe habitat ini yaitu, Piper adumkun, Hybiscus sp., Premna corimbosa, dan jenis-jenis liana. Masyarakat manfaatkan hutan tersebut sebagai tempat berkebun atau berladang, dan juga tempat berburu satwa.

\section{c. Hutan Pantai}

Jalur pada hutan pantai tepatnya berada pada bagian hilir sungai, terletak pada kordinat $\mathrm{S}$. $00^{\circ} 34^{\prime} 56.0^{\prime \prime}, \quad$ E. $133^{\circ} 10^{\prime} 31.8$, dengan ketinggian tempat 6-20 m dpl. Bentuk topografi landai, memiliki tekstur tanah berpasir. Vegetasi pada hutan ini didominansi oleh Terminalia catpa, Baringtonia asiatika, Hibiscus tellecua, Pongamia pinata, Pandanus sp. dan beberapa jenis tumbuhan bawa serta jenis liana, dan juga beberapa tumbuhan air seperti tebu air dan beberapa jenis tumbuhan lainnya. Sepanjang pesisir hutan pantai merupakan daerah bekas perladangan masyarakat yang telah di tinggali dan sudah di tumbuhi oleh semak belukar. Masyarakat memanfaatkan hutan tersebut juga untuk berburu satwa, seperti tikus tanah (bBandikut) dan kelelawar, selain itu tepian pantai dari lokasi ini sering dikunjungi oleh penyu yang melakukan peneluran pada pantai tersebut, sehingga masyarakat juga melakukan perburuan penyu pada pantai tersebut.

Lokasi penelitian ini berada pada areal hutan di kampung Saukorem distrik Amberbaken kabupaten Tambrauw, tepatnya berada di areal hutan sepanjang sungai Asei. Lokasi ini termasuk salah satu dari 19 wilayah endemisitas herpetofauna, tepatnya berada pada daerah Pegunungan Tambrauw dan Arfak (vogelkop), (Conservation Internasional, 1999). Sungai Asei berada di sekitar Cagar Alam Pegunungan Tambrauw Timur, tepatnya di kampung Saukorem.

\section{KESIMPULAN}

Berdasarkan penelitian yang dilakukan berhasil didata sebanyak 25 jenis reptil yang terdiri dari 12 jenis kadal, 2 jenis biawak, 10 jenis ular, dan 1 jenis penyu. Jenis reptil yang ditemukan terdapat beberapa jenis yang dilindungi oleh Peraturan Pemerintah (PP No. 7 Tahun 1999) dan dalam CITES dan IUCN yaitu Varanus salvador (appendiks II), Varanus indicus (appendiks II) dan Chelonia mydas IUCN, yaitu terancam punah dan CITES (appendiks I). Hasil perhitungan Indeks keanekaragaman jenis $\left(H^{\prime}\right)$ dan kemerataan jenis tertinggi terdapat pada tipe habitat hutan pantai $H^{\prime}(1,43)$ kemudian di ikuti oleh hutan sekunder $H^{\prime}(1,39)$, sedangkan keanekaragaman jenis terendah pada habitat hutan primer $H^{\prime}$ $(1,26)$. Kemerataan jenis $E$ ' tertinggi terdapat pada hutan pantai $E^{\prime}(0,49)$. Perhitungan indeks sorensen, reptil antara tipe habitat menunjukkan 
kisaran indeks antara 50 - 77 atau $50-77 \%$. Jenis reptil di sungai Asei, tersebar di tiga tipe habitat, yaitu pada hutan primer, dan hutan sekunder, dan hutan pantai. Ketiga habitat tersebut terletak dari hulu sungai ke hilir sungai.

\section{DAFTAR PUSTAKA}

Beehler BM and Marshall A. 2007. The ecology of Papua, Part One. Periplus Editions. Hong Kong. (Hal. 564-605).

Brown WC. 1991. Lizard of genus Emoia (Scincindae) observation on their evolution and biogeography. California Academy Of Science And The Cristensen Research Institute. San Francisco.

Campbell NA. 2004. Biologi. Edisi Keilima Jilid 3. Jakarta: Erlangga.

Conservation International. 1999. Peta lokakarya prioritas konservasi di Irian Jaya. Lokakarya Penentuan Daerah Prioritas Konservasi Keanekaragaman Hayati Irian Jaya. Biak, Papua.

Conservation International, 2000. Teknik Survei lapangan progam penilaan cepat (Rapid Assessmant Program).

Goin CJ. 1971. Introduction to herpetology. W.H. Freeman \& Co Ltd.

Kartikasari SN, Marshall AJ and Beehler BM. 2012 .Ekologi Papua. Seri Ekologi Indonesia, Jilid VI.
Krey K. 2002. Keanekaragaman herpetofauna di Sekitar Sungai Kamtabai Desa Waifoi dan Di Sekitar Sungai Bayon Desa Lopinton Kepulawan Raja Ampat Kecamatan Waigeo Selatan Kabupaten Sorong. Skripsi Fakultas Keguruan dan Ilmu Pendidikan . Universitas Negeri Cenderawasih, Jayapura. (Tidak di Terbitkan).

Krey K. 2009. Herpetofauna di sekitar kampung Kaliki, Kabupaten MeraukePapua.

Magurran A. 1988. Ecological diversity and its measurement. University Press Cambridge.

Mattison C. 1992. Snakes of the world. New York. Fact on Files Inc.

McCoy M. 1980. Reptiles of the Solomon Islands. Wau Ecology Institute. PNG.

O'Shea M. 1996. A guide to the snake of Papua New Guinea. Independent Publishing.

Petocz, R.G. 1987. Konservasi alam dan pembangunan di Irian Jaya. PT. Temprint. Jakarta.

Sidik I dan Mumpuni. 1999. Pengelolaan koleksi herpetologi dalam Suharjo. Y. R (Ed): Buku pengelolaan koleksi spesimen zoologi. Balai Penelitian dan Pengembangan Zoologi, Pusat Penelitian dan Pengembangan Biologi, Lembaga Ilmu Pengetahuan Indonesia. Bogor.

Zug GR. 1993. Herpetology: An introductory biology of ampibians and reptiles. Academic Press. New York. 